\title{
Article \\ Shopping Behavior in the Context of the Digital Economy
}

\author{
Katarina Repkova Stofkova ${ }^{1, *}$, Dominik Laitkep ${ }^{1}$ and Zuzana Stofkova ${ }^{2}$ \\ 1 Department of Communication, University of Zilina, Univerzitna 1, 01026 Zilina, Slovakia; \\ dominik.laitkep@fpeas.uniza.sk \\ 2 Department of Economy, University of Zilina, Univerzitna 1, 01026 Zilina, Slovakia; \\ zuzana.stofkova@fpedas.uniza.sk \\ * Correspondence: katarina.stofkova@fpedas.uniza.sk; Tel.: +421-415-133-136
}

check for updates

Citation: Stofkova, Katarina Repkova, Dominik Laitkep, and Zuzana Stofkova. 2022. Shopping

Behavior in the Context of the Digital Economy. Journal of Risk and Financial Management 15: 39. https://doi.org/ 10.3390/jrfm15020039

Academic Editor: Khaled Hussainey

Received: 13 November 2021

Accepted: 10 January 2022

Published: 18 January 2022

Publisher's Note: MDPI stays neutral with regard to jurisdictional claims in published maps and institutional affiliations.

Copyright: (C) 2022 by the authors. Licensee MDPI, Basel, Switzerland. This article is an open access article distributed under the terms and conditions of the Creative Commons Attribution (CC BY) license (https:// creativecommons.org/licenses/by/ $4.0 /)$.

\begin{abstract}
Consumers shop to meet their needs. When buying, they always compare and evaluate the available alternatives to the goods. The purchasing process involves various factors. These factors can also be described as attributes that can affect consumers during the purchasing process. Identifying important attributes can be really challenging for the digital economy and global markets. Most retailers do not have accurate knowledge of the attitudes and characteristics of their customers, which greatly affects purchasing processes. Combining accurate knowledge of the combination of attributes can increase revenue and improve retailers' market position. The aim of this paper is to present the results of primary research, processed by reducing the number of attributes influencing purchasing behavior using factor analysis. The target group of the primary research was women who bought mostly online. The most important factors influencing women's shopping behavior are traditional influences such as online payment for orders, diversity of delivery options, nicely crafted sites, and store reviews, but also the influences of social networks. Another important factor is the possibility of in-store purchases and payments for cash purchases. The results of this research will complement the view of women's consumer behavior, thus creating the conditions for retailers to react to this target group.
\end{abstract}

Keywords: purchasing behavior; e-commerce; social networks; consumers; women's purchase intentions

\section{Introduction}

New information technologies have greatly simplified business and reduced costs. New products and services can be created much more easily, with almost non-existent barriers to communication between companies, consumers, and business partners. These new technologies give the companies that use them a much better chance of succeeding in the market.

The internet offers much more than the mediation of sales. The digital era provides an increasingly greater space for retailers to promote their businesses through social media, emails, web pages, and other digital marketing tools (Civelek et al. 2020). Retailers are using e-commerce for expanding their position on the market, as they can easily, quickly, and costly allocate more customers, as well as the best suppliers and the most suitable business partners internally and internationally (Vijayasarathy 2004). Reducing administrative costs, as well as lower prices and overheads, are other reasons why the global computer network is thrust into the center of attention. Achievements such as the internet and the growth of emerging economies further accelerate global exchanges and changed their nature, especially now, during the COVID-19 pandemic.

Nowadays, by using the internet, consumers can buy anything at any time, usually with no charge for the service, and they are guaranteed fast delivery with the favorable policy of returning the goods (Alraja and Kashoob 2019). However, it is important to point out that, the internet is a global medium where users and potential customers retain 
a degree of regional specificity, regardless of the elimination of a significant number of physical barriers (Pollák et al. 2021).

The Organization for Economic Co-operation and Development (OECD) defines ecommerce as any commercial transaction carried out by natural or legal persons, based on electronic data processing and transmission (OECD 2021). A similar definition was given early in 1998 by the World Trade Organization (WTO), which includes e-commerce in both products that are sold and paid for online but delivered in physical form and products that are delivered online in digital or electronic form (WTO 1998). However, shopping online has never been common and accessible to everyone. The use of electronic devices for commerce has experienced the greatest progress, especially with the arrival of world-renowned sites such as eBay and Amazon in the early 1990s (Taher Al-Lami 2021).

The purchasing process is directly related to wishes and desires that create demand in customers for specific needs, services, products. Consumers are able to fulfill these desires directly through shopping. Defining needs is not easy due to the fact that most customers are not aware of their needs and do not know how to define them. You also need to realize that every customer is different and each of them requires something different (Lim et al. 2016).

Consumers are also affected by various advertisements from new media (Nielsen 2018). It is important for every enterprise to know the needs of their customers and determine their priorities and shopping behavior. Jeon et al. indicate that in e-commerce, there is a link between offline, online, and mobile channels that influence consumers' shopping behavior through complex factors such as neuroticism (Jeon et al. 2021). Neuroticism can be characterized as a level associated with depression, anger, embarrassment, and anxiety (Barnett et al. 2015). It can therefore be argued that neuroticism, in this case, is manifested in particular by complex and unpredictable patterns that, as a result of their occurrence, affect the efforts of traders to attract their potential customers (Drugău-Constantin 2019).

Slovakia is a small European country, with 5.4 million inhabitants, which spent over 1.36 billion euros in online stores in 2019 . The popularity of online shopping is stronger every year, with almost 6 out of 10 online store visitors making a purchase. This trend makes Slovakia one of the European leaders in online shopping (Heureka 2019; Shoptet 2021).

Understanding customers purchasing decisions is very challenging because it is a dynamic and often complex process. The buyer has to face a complex of problems, and their behavior is mainly influenced by many situational factors. This process has existed in society since the beginning of trading and when people took on the role of shoppers having a choice among several purchasing alternatives (Fu et al. 2020).

\section{Materials}

With the development of modern technologies and the simplification of communication channels, completely new forms of sales have emerged. Selling products via the internet, dynamic and attractive sales support, and advertising via the internet, all allow enterprises to use modern technologies and simplify their own sales activities while reducing operating costs.

The most important effects of globalization include more mobility for factors of production. There are growing numbers of enterprises entering international relations through a global corporate strategy. Globalization has forced enterprises to be competitive on a global scale, which results in efforts to make the most effective use of comparative advantages. This gives space to the market, and its natural laws provide greater benefits to consumers. Today's enterprises are more likely flexible in learning, acquiring, and implementing knowledge. This fact is based on new perspectives on entrepreneurship, because traditional business models are no longer correspond to the dynamics of change and the principles of the functioning of new markets (Aslam et al. 2020).

Building an information society brings technical, legislative, and personal challenges. Today's society is based on information, knowledge, and skills that need to be developed 
and to prevent the emergence of the digital divide. A vision for the future predicts that at least the minimum level of digital skills will be required for most jobs, new positions will arise due to digitization (Misik et al. 2018).

In the new economy, a large part of economic activities is transformed into digital form, which results in the interconnection of individual organizations into one whole enterprise and the creation of new network structures, which are characterized by sharing the use of information and knowledge resources (Zafar et al. 2019). New economies and technologies are opening up new possibilities, such as a new form of work called freelancing, which has become popular. Attitudes and behaviors have changed, and so have the common needs. It can therefore be argued that consumer attitudes are changing as a result of a technology-driven sharing economy (Graessley et al. 2019).

In other words, we can speak of a phase of a shared economy. The digital economy is generally an economy based on the widespread use of the internet, computers, and other electronic devices. The current digital technology is characterized by its specific characteristics, wide application, and strong mutual complementarity (Ghobakhloo 2020).

Probably, each entity participating in electronic commerce at least once met with some risk of e-commerce without realizing the extent of the potential threat. Economic aspects and the context of globalization have their natural basis and starting point in the globalization of the company. It is reflected in the fact that the company is gaining real opportunities for expansion in new markets and, at the same time, is under increasing pressure (Jabbour et al. 2019).

On the other hand, consumers are benefiting from the fact that, with lower transport costs and reduced import tariffs, products produced are far from becoming available to them. Manufacturers who are able to export their products also benefit because they have the opportunity to sell and operate in a much larger and wider market.

The European Union Committee on the Internal Market and Consumer Protection defines a consumer as any person who is acting primarily for purposes that are not related to their trade, business, or profession. The term of purchasing behavior is defined as the behavior that customers exhibit when searching for, purchasing, using, evaluating, and handling a product or service from which they expect to meet their needs. Consumer behavior according to (Hoyer and Macinnis 2009) encompasses summary consumer decisions with respect to the acquisition, quantity, and equipment of goods, services, activities, experiences, people, and thought decision units.

There are various marketing strategies and tactics that seek to influence one or more dimensions of consumer behavior that need to be considered. Usage of marketing is visible from small to large companies by raising the profile of their large portfolio in advertisements such in shopping malls, billboards, but also television and the internet. Marketing is an essential business strategy (Hollowell et al. 2019). In addition to marketing, it is important to find out the added value of the offered products. If a company offers value to customers along with marketing, customers also return that value to the company. This creates a certain customer loyalty to the company. Therefore, customers choose the company they remember when making a purchase decision (Meilhan 2019). Consumers usually trust the product from the company when they approve and trust it, and the company should constantly maintain its customers by providing high-quality services (Popescu and Ciurlău 2019).

Consumer behavior is the result of a set of different influences and conditions from which can be specified individually, on both microsocial and macrosocial levels. Decision making of individuals is related to spending their own resources such as time, money, effort on items related to shopping. This includes questions of what, where, why, when, and how often customers buy items, as well as how often they use them, how they rate them after purchase, and what impact those ratings have on future purchases.

Nowadays, the key to success for retailers is using innovations. It is essential for them to take advantage of all the opportunities that the age of the Internet offers them, as it is important for them to know how to focus more precisely focus on the right group of people 
(Bucko et al. 2018). Since e-commerce is providing many new opportunities for consumers, retailers need to find the best way to attract the most number of customers among the massive competition. Online retailers need to design their website in such a way to make them user friendly and actively manage the social media marketing to channel traffic to their online website (Lim et al. 2016).

E-commerce provides many new opportunities for consumers and retailers (Gburova and Fedorko 2018). E-shop has many advantages over the stores. For example, customers can book or buy goods anywhere, anytime. There are many companies that, even for reasons of cost-effectiveness, do not have their own stores. Some only have an e-shop, while others may share a space with another company or have a virtual headquarters. Recently, most of the top retailers opening up showrooms where the customer can "touch" and take their online orders (Lim et al. 2016).

According to a research study on the Slovakian context, smartphones are becoming a regular device for shopping and other various online activities. The use of smartphones in the purchasing process represents a growing trend that is forcing companies to innovate and adapt points of interaction with the customer in order to achieve a positive customer experience (Kakalejcík and Bucko 2018). For women, the second most frequently used digital device for online purchasing was the smartphone (Stefko et al. 2019).

There is a large number of consumers online, especially since the last decade, and it is still a growing market, with its attention focused on new online marketing channels and social media platforms (Civelek et al. 2020). New technologies lead companies to think creatively. A new essential need arising from the connection of mobile phones and social networks is using influencers for promotion. A 2021 study points to vague conclusions about statistical evidence of consumer shopping behavior in social media but suggests that some social media have an impact on consumer behavior. We concur with this finding (Ali Taha et al. 2021).

Influencers have the ability to reshape or change the mindset of others. A person that has the status of influencer has valuable experience, and his or her opinion or advice is considered important and trustworthy in society (Hennessy 2018). Trustworthiness is connected also to social suitability. Social sustainability is the process of recognizing and managing the positive and negative business, environmental, economic, and technological impacts on people. During using social networks, potential customers can manifest a change in neurophysiological functioning in the case of perception of the content as well as of a person or company. This change affects their trust and their opinions, consumer knowledge, and decision-making behavior (Mirică 2019).

Social sustainability is a trend and ultimate goal for enterprises (Dempsey et al. 2011). The global interconnection and globalization in the world bring very sudden changes affecting wide spheres of life. Changes in lifestyle advance hand in hand with progress in society (Soltes and Stofko 2017).

\section{Methods}

The main objective of this paper is to identify the factors that influence the consumer buying process in conditions of the global market. The aim of this paper is to eliminate the number of criteria affecting online purchasing and create new factors that would contain aggregated information.

The results of the research were analyzed on the basis of a review of the theoretical part consisting of professional contributions, books, and scientific articles. A comparison method was also performed to find common elements of the analysis. We decided to examine the key factors in shopping behavior because a comprehensive atmosphere survey (Nielsen 2018) for SAEC shows that women shop online slightly more often and more than men; therefore, what factors influence them to make a purchase were of interest.

If we proceed from the assertion that women shop online more often than men, it is interesting to determine which factors influence shopping the most. The results can serve businesses to better focus on those customers, thereby increasing their market share. 
To achieve the goal of the paper, two hypotheses and one research question were set as follows:

Hypothesis 1 (H1). Women's online shopping behavior is more affected by influencers and online advertising than by offline advertising.

Hypothesis 2 (H2). For women shopping online, the option to pay online is more important than paying in cash.

Q1. What is the most important factor that influences women's online shopping?

An exploratory factor analysis was performed to achieve the goal of the study. Factors provide identification of key elements that businesses should focus on in this particular case (Jankalova and Kurotova 2020).

We concluded this primary research by using electronic polling that occurred with a choice of answers to several questions; the response options were based on a five-point Likert scale (Tutz 2021). Respondents chose their answers from modal options in the range from 1 = very important to $5=$ not important at all.

The questions were based mainly on studies described in Section 2. Materials that supplemented the results were based on claims that social networks may influence the purchasing behavior of potential customers (Ali Taha et al. 2021) but also based on research confirming that the COVID-19 pandemic created new shopping habits and forced consumers to devote more time to the decision-making process (Valaskova et al. 2021).

We provide the summary of questions from the survey related to attributes in Table 1. Each of the attributes has equal weight with respect to their individual importance.

The input data of the exploratory factor analysis were derived from the primary survey, which was focused on finding out which attributes influence the shopping behavior of customers in the Slovak Republic. From the perspective of a scientific article, customers were women who were respondents in the questionnaire investigation realized in November 2019. The questionnaire survey was conducted by the publication on social networks such as Facebook and on internet discussion forums. During the questionnaire survey, we managed to address 1814 respondents. Due to the intention of the survey, we filtered the target sample of respondents who were Slovaks, female, and who shopped on the internet at least once in the past. After filtration, we reached the number of 1324 respondents in the age group 15 to 69 years with an average age of 25.94 years.

In order to calculate the minimum sample size of the primary survey conducted using an electronic survey, it was necessary to find out how many women inhabitants in the Slovak Republic are aged 15-69 years. At first of July 2019, the number of selected inhabitants in the Slovak Republic was 2,025,585 (Statistical Office SR). After determining the number of inhabitants of the sample spectrum, we used the following formula to calculate large basic files:

$$
\mathrm{n} \geq \llbracket \mathrm{t} /(1-\alpha / 2) \nabla^{\wedge} 2^{*} \sigma^{\wedge} 2 / \Delta^{\wedge} 2
$$

where

$\mathrm{n}$-is the minimum sample size (minimum number of respondents);

$\mathrm{t} \_(1-\alpha / 2)$ - is the critical value determined from the tables (critical values of the normalized normal distribution);

$\sigma 2$-is the spread calculated from the standard deviation;

$\Delta$-is the maximum allowable margin of error.

Then, we put the values into the following formula:

$$
\mathrm{n} \geq \llbracket 1.96 \rrbracket^{\wedge} 2 /[0.03)^{\wedge} 2 \mathrm{x}[0.5)^{\wedge} 2=1067.11 \doteq 1068 \text { respondent }
$$


Table 1. Attributes—questions from primary research.

\begin{tabular}{|c|c|}
\hline Number & Attributes \\
\hline 1 & Importance of social networks \\
\hline 2 & The quality of the content on social networks \\
\hline 3 & Truthfulness of the social network content \\
\hline 4 & The importance of influencers \\
\hline 5 & Influencer's option \\
\hline 6 & Promo codes form influencers \\
\hline 7 & Sales actions \\
\hline 8 & Promo codes for first purchase \\
\hline 9 & Companies' activities on social networks \\
\hline 10 & Purchasing in store \\
\hline 11 & Online purchasing \\
\hline 12 & Website design \\
\hline 13 & Impulsive shopping \\
\hline 14 & Delivery methods \\
\hline 15 & Free delivery \\
\hline 16 & Offline advertising \\
\hline 17 & Purchase through apps \\
\hline 18 & Sustainable business \\
\hline 19 & YouTube business activities \\
\hline 20 & Business reviews \\
\hline 21 & Purchasing in known company \\
\hline 22 & Cash payment \\
\hline 23 & Online payment \\
\hline 24 & Crypto payment \\
\hline 25 & Newsletter \\
\hline
\end{tabular}

After substituting the values into the formula for calculating the sample of large basic files, we found that at $95 \%$ reliability and 3\% error range, the minimum sample is 1068 respondents. In carrying out primary research, we managed to reach 1324 respondents. Therefore, we can conclude that the requirement to meet the minimum sample size was met. Subsequently, exploratory factor analysis was used to evaluate the results of the primary survey, in which seven factors were identified through this analysis, as can be seen in Table 1.

For Figure 1, we carried out a Scree plot to check the identification of the facts. It is a diagram that confirms the determination of the number of factors from Table 2. The Scree plot is arranged according to total intrinsic values and is used to determine which of the factors are significant and which are not. In principle, an important factor is a factor that has a total intrinsic value greater than 1 . In this case, regarding values higher than 1 in the control chart, we achieved the same 7 identified factors (Bro and Kier 2003). 


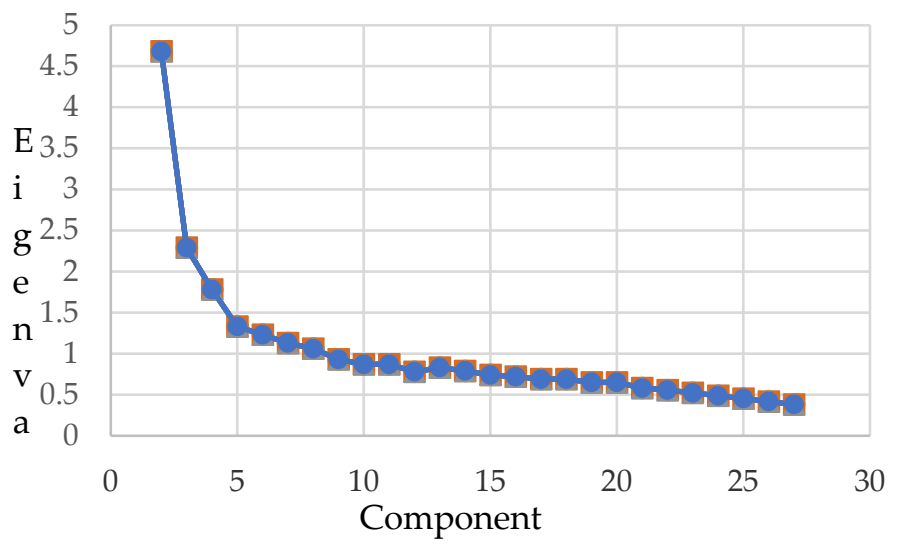

Figure 1. Scree plot shows the real number of potential factors, which is expressed by a scree plot. The scree plot is used to determine other interpretable factors with their own numbers and variance, which needs to be an eigenvalue higher than 1.

Table 2. Variance explained.

\begin{tabular}{|c|c|c|c|c|c|c|c|}
\hline \multirow[b]{2}{*}{ Component } & \multicolumn{3}{|c|}{ Initial Eigenvalues } & \multirow[b]{2}{*}{ Component } & \multicolumn{3}{|c|}{ Rotation Sums of Squared Loadings } \\
\hline & Total & $\begin{array}{c}\% \text { of } \\
\text { Variance }\end{array}$ & $\underset{\%}{\text { Cumulative }}$ & & Total & $\begin{array}{c}\% \text { of } \\
\text { Variance }\end{array}$ & $\begin{array}{c}\text { Cumulative } \\
\%\end{array}$ \\
\hline 1 & 4.68 & 18.70 & 18.70 & 1 & 2.35 & 9.41 & 9.41 \\
\hline 2 & 2.29 & 9.16 & 27.86 & 2 & 2.04 & 8.17 & 17.59 \\
\hline 3 & 1.78 & 7.12 & 34.98 & 3 & 1.84 & 7.35 & 24.94 \\
\hline 4 & 1.33 & 5.34 & 40.32 & 4 & 2.42 & 9.70 & 34.63 \\
\hline 5 & 1.23 & 4.93 & 45.24 & 5 & 1.77 & 7.08 & 41.71 \\
\hline 6 & 1.13 & 4.53 & 49.78 & 6 & 0.30 & 1.18 & 42.89 \\
\hline 7 & 1.06 & 4.24 & 54.02 & 7 & 0.42 & 1.69 & 44.58 \\
\hline
\end{tabular}

Exploratory factor analysis was applied on the open-source platform of the PSPP software solution and aimed to summarize and reduce the data obtained by means of a questionnaire survey. With the help of exploratory factor analysis, it is possible to find the smallest possible number of factors that best describe the behavior of the examined variables, which in our case, were the attributes asked in the primary survey (Hu and Bentler 2009). The advantage of this analysis is in the rotation of factors, seeking to define a matrix that is acceptably interpretable. The relationships between the variable attributes are expressed by the so-called factor load, which serves to explain the correlation between the variables and a smaller number of factors (Polman and Wu 2020).

The ideal load condition is the relationship of the variables to the identified factors in the highest correlation values of +1 . The best interpretation of the correlation between variables is when the variables have one highest interpreted value for one factor and for the others in the smallest possible values, reaching -1 . A value of +1 is a direct relationship, while $\mathrm{a}-1$ is an indirect relationship. Values closest to +1 present that the variable best satisfies the given factor (Duncan et al. 2015).

\section{Results}

A total of seven identified factors (Table 2, column components) were derived from the use of a perpendicular distribution of the rotation of the matrix, also known as varimax, which provides an eigenvalue distribution that is only relevant for an eigenvalue greater than 1 . 
Varimax ensures that each of all the 25 variables belongs to only one factor while trying to maximize the variance and minimize the number of variables that are most correlated with each factor. A correlation matrix was used to identify the number of significant factors, due to the higher predictive value. The number of significant factors is seven, but they have a different amount of eigenvalue, which is listed in the column total eigenvalue. The intrinsic value of the first factor is 4.68 . Seven factors explain $54.02 \%$ of the variability of all variables.

Based on our own numbers, we found that the seven factors would be a sufficient number of factors for our analysis. This number of factors explained $54.02 \%$ of the variance of the data. As the non-rotated solution was not sufficient, the results were not clear, and therefore, we decided to try the rotation of varimax, equamax, and quartimax. All types of rotation gave us almost similar results. We decided to continue using the varimax method.

After rotation, it is possible to determine which of the correlation values of individual variable attributes can be assigned to factors. The rotation of the factor matrix also serves for a better interpretation of the results and also for the elimination of deviations in the variance of the identified factors, which in the previous step, may be positively correlated with a larger number of variables. In this way, it is possible to identify their load on a given factor with a higher percentage of explained variability.

Even in this case, it is a load expressed in the range from -1 to +1 (Giao 2020; Alves de Almeida et al. 2018). From the presented rotated factor matrix given in Table 3, which is the main output of the exploratory factor analysis, it is possible to classify the relevant attributes to the factors by assigning their highest value.

For factors 1 to 7 , a significance value was determined, which represents the importance of the given factors based on the average values of the questionnaire responses.

Based on the data obtained, which are presented in Tables 3 and 4, we could proceed to the interpretation of the achieved results. From the 25 variables that we analyzed through factor analysis, we characterized them into seven basic factors. The given seven factors represent the relationship between the individual analyzed attributes.

Factor No. 1: "influencer" contains variables whose acquired value is from 0.46 to 0.86. This factor represents a combination of variables such as social media advertisements, reviews, and promo codes from influencers along with impulsive shopping.

Factor No. 2: "image" contains variables whose acquired value is from 0.41 to 0.62 . This factor represents a combination of variables such as website design, free delivery methods, reviews from merchants, and making a purchase from a well-known merchant. Based on the results of the factor analysis, we confirmed the response to our research question-namely, that "image" is the most important factor that influences customers when making a purchase. This factor is the most significant based on the determination of the significance value, given in Table 4 in the relevant column.

Factor No. 3: "stores" contains variables whose acquired value is from 0.44 to 0.87 . This factor includes variables such as the ability to purchase in stores and payment in cash.

Factor No. 4: "social networks" contains variables whose acquired value is from 0.61 to 0.77. Factor No. 4 represents a combination of variables, such as the activities of enterprises on social networks, along with discounts and promo codes for the first purchase.

Factor No. 5: "online space" contains variables whose acquired value is from 0.47 to 0.61. This factor represents a combination of variables such as offline advertising, merchant responsibility, merchant activity on YouTube, the ability to pay with cryptocurrencies, and also the importance of newsletters.

Factor No. 6: "online purchasing" contains a variable whose acquired value is 0.46 Factor No. 6 contains only one variable-the online purchase method. This attribute presents a separate category and a separate factor.

Factor No. 7: "Relationship with customer" contains variables whose acquired value is from 0.23 to 0.71 . This factor represents a combination of variables such as social media activities, along with mobile app shopping and online payments. The smallest correlation of the coefficient was the value 0.23 for online payment, which showed the lowest measured 
value and therefore may be seen as irrelevant. Nevertheless, we decided to include it, as online payment, together with mobile app shopping and social media activities, is very common nowadays (Figure 1).

Table 3. Rotated component matrix.

\begin{tabular}{|c|c|c|c|c|c|c|c|}
\hline \multirow{2}{*}{ Attributes } & \multicolumn{7}{|c|}{ Component } \\
\hline & 1 & 2 & 3 & 4 & 5 & 6 & 7 \\
\hline 1 & 0.27 & 0.06 & -0.03 & 0.23 & -0.05 & -0.01 & 0.71 \\
\hline 2 & 0.35 & 0.16 & -0.03 & 0.18 & -0.05 & 0.02 & 0.71 \\
\hline 3 & 0.00 & 0.33 & 0.07 & -0.01 & 0.02 & -0.01 & 0.54 \\
\hline 4 & 0.86 & 0.03 & 0.05 & 0.03 & 0.23 & 0.03 & 0.05 \\
\hline 5 & 0.66 & 0.04 & 0.05 & 0.12 & 0.19 & 0.01 & 0.18 \\
\hline 6 & 0.57 & -0.03 & -0.01 & 0.42 & 0.12 & 0.01 & 0.18 \\
\hline 7 & 0.16 & -0.03 & -0.03 & 0.77 & 0.02 & 0.02 & 0.08 \\
\hline 8 & 0.07 & 0.08 & -0.02 & 0.69 & 0.14 & 0.03 & 0.15 \\
\hline 9 & 0.08 & 0.04 & -0.05 & 0.61 & 0.19 & -0.02 & 0.23 \\
\hline 10 & -0.08 & -0.19 & 0.87 & 0.01 & 0.20 & 0.25 & 0.03 \\
\hline 11 & 0.12 & 0.25 & -0.73 & 0.22 & -0.12 & 0.46 & 0.04 \\
\hline 12 & 0.12 & 0.54 & -0.17 & -0.01 & 0.11 & 0.02 & 0.20 \\
\hline 13 & 0.46 & 0.04 & -0.26 & 0.36 & 0.14 & 0.04 & -0.02 \\
\hline 14 & -0.04 & 0.55 & 0.08 & 0.22 & -0.18 & -0.01 & 0.07 \\
\hline 15 & 0.12 & 0.41 & 0.14 & 0.35 & -0.07 & -0.03 & -0.23 \\
\hline 16 & 0.10 & 0.02 & 0.21 & 0.17 & 0.61 & -0.06 & 0.07 \\
\hline 17 & -0.11 & 0.13 & -0.24 & 0.16 & 0.22 & 0.03 & 0.42 \\
\hline 18 & -0.11 & 0.45 & -0.03 & -0.21 & 0.47 & 0.04 & 0.14 \\
\hline 19 & 0.34 & 0.17 & 0.03 & 0.09 & 0.55 & 0.04 & 0.04 \\
\hline 20 & 0.05 & 0.62 & 0.09 & 0.07 & -0.03 & -0.02 & 0.16 \\
\hline 21 & 0.19 & 0.53 & 0.21 & 0.18 & -0.13 & -0.01 & 0.07 \\
\hline 22 & 0.12 & 0.19 & 0.44 & 0.15 & 0.01 & -0.05 & -0.05 \\
\hline 23 & -0.24 & 0.21 & -0.24 & 0.22 & 0.13 & 0.02 & 0.23 \\
\hline 24 & 0.20 & -0.16 & -0.10 & 0.09 & 0.49 & 0.02 & -0.09 \\
\hline 25 & 0.21 & -0.03 & 0.02 & 0.36 & 0.51 & 0.00 & 0.02 \\
\hline
\end{tabular}

Table 4. Rotated component matrix.

\begin{tabular}{ccc}
\hline Serial No. & Factor & Signifiance Value \\
\hline 1 & No. 2 & {$[(3.52+4.19+3.77+3.89+3.59) / 5]=3.79$} \\
\hline 2 & No. 7 & {$[(3.22+3.23+4.30+3.32+3.68) / 5]=3.55$} \\
\hline 3 & No. 3 & {$[(3.16+3.44) / 2]=3.30$} \\
\hline 4 & No. 6 & {$[(3.11) / 1]=3.11$} \\
\hline 5 & No. 4 & {$[(2.74+2.79+2.79) / 3]=2.77$} \\
\hline 6 & No. 5 & {$[(2.28+3.50+1.97+1.38+1.97) / 5]=2.22$} \\
\hline 7 & No. 1 & {$[(1.77+2.07+2.36+1.71) / 4]=1.97$} \\
\hline
\end{tabular}


Based on the results of the factor analysis, it is possible to confirm that this is the second-most important factor that affects customers when making a purchase, based on the determination of the significance value listed in Table 4 in the relevant column.

\section{Discussion}

Based on the results of a factor analysis of the questionnaire survey, it can be argued that from the 25 variable attributes that are common parts of business and marketing activities, it is possible to identify key factors influencing the shopping behavior of consumers, specifically Slovak women.

From all of the factors, we identified key factors to be factors No. 2, 7, and No. 3 . The most important factor, "image", shows the importance for merchants to offer a nicely designed website environment, offering more order delivery options with free delivery. These results are in agreement with the results of another studies (Ali Taha et al. 2021). It was revealed that women prefer social media more based on images and personal content such as Facebook, Instagram, etc. An important element of this factor is also the popularity and general knowledge of the enterprise in the market and retaining satisfied customers, as it is important for them to make a purchase from a well-rated merchant. Pollák et al. (2021) stated that companies are exposed to significant business risk under the pressure of continuous changes in the global market. Another important factor clarifies the importance of all activities traders engage in on social networks. In this context, we also note that, in agreement with (Bucko et al. 2018), unfulfilled customer expectations may cause companies to expend more additional resources to reassure customers.

The results of our research also confirmed a report by Jungle Scout (2021) in the fourth quarter of 2021, which showed that women tend to favor the same vendors, expect fast delivery of their online orders, and want to buy products with many great reviews.

Social networks are a very influential aspect in this case. As many as $98 \%$ of the respondents use the world's most popular social networks, Facebook and Instagram, where they consider the truthfulness and quality of the shared posts.

Since users use social networks, users most often access networks via mobile applications; thus, it is important for merchants to also offer the option of making a purchase using mobile applications. Significant factors also included a factor including the possibility of purchasing in stores, together with payment in cash. We also attached importance to this fact due to the growing popularity of order picking in the enterprises' stores themselves.

\section{Conclusions}

Online shopping has become a common part of the lives of all people of all ages. With increased efforts by companies to succeed in the global internet market, all businesses seek to bring a positive experience to their customers, from which they expect higher revenues while minimizing all factors that could bring a negative customer experience that would permanently lose customers.

The results of factor analysis conducted on a sample of 1324 women present interesting findings with respect to defined variables, depending on the factors affecting the buying behavior surveyed target group. The research results also reveal the answers to our hypotheses. H1 is confirmed, i.e., women are more affected by advertising and online influencer, compared with offline advertising. $\mathrm{H} 2$ is also confirmed, i.e., in today's modern age, cash payment moves to the background. However, we cannot confirm that our findings would be the same if the research did not focus only on Slovak customers but rather was global. However, we assume that customers do not buy only in the context of Slovak e-shops.

The conclusions of this research reveal the fact that consumer behavior in the market, which features enterprises, is affected by globalization and dynamic individual variables. Is it obvious that in a few years the examined variables will be completely different? No one can predict what these variables will represent, and we must not forget the fact that in addition to changes in generations of consumers and their preferences, technologies and 
marketing promotions used by both enterprises and their customers can also change. We can confirm that the obtained results were affected due to measures related to COVID-19, as the pandemic affected customers' purchasing patterns (Agus et al. 2021). This paper led us to conclusions that can be extended, serving as the basis for further research.

Author Contributions: Conceptualization, K.R.S., D.L., and Z.S.; methodology, K.R.S., D.L., and Z.S.; software, D.L.; validation, K.R.S., D.L., and Z.S.; formal analysis, D.L. and Z.S.; investigation, D.L.; resources, K.R.S., D.L., and Z.S.; data curation, K.R.S.; writing-original draft preparation, K.R.S., D.L., and Z.S.; writing-review and editing, K.R.S., D.L., and Z.S.; visualization, D.L.; supervision, K.R.S. All authors have read and agreed to the published version of the manuscript.

Funding: This research received no external funding.

Institutional Review Board Statement: Not applicable.

Informed Consent Statement: Not applicable.

Data Availability Statement: In this section, please provide details regarding where data supporting reported results can be found, including links to publicly archived datasets analyzed or generated during the study.

Acknowledgments: This paper is an output of the project KEGA 052ŽU-4/2021.

Conflicts of Interest: The authors declare no conflict of interest.

\section{References}

Agus, Anna Amalyah, Gatot Yudoko, Nurbudi Mulyono, and Taliya Imaniya. 2021. E-Commerce Performance, Digital Marketing Capability and Supply Chain Capability within E-Commerce Platform: Longitudinal Study Before and After COVID-19. International Journal of Technology 12: 360-70. [CrossRef]

Ali Taha, Viktória, Tonino Pencarelli, Veronika Škerháková, Richard Fedorko, and Martina Košíková. 2021. The Use of Social Media and Its Impact on Shopping Behavior of Slovak and Italian Consumers during COVID-19 Pandemic. Sustainability 13: 1710. [CrossRef]

Alraja, Mansour Naser, and Maryam Ali Said Kashoob. 2019. Transformation to electronic purchasing: An empirical investigation. TELKOMNIKA (Telecommunication Computing Electronics and Control) 17: 1209-19. [CrossRef]

Alves de Almeida, Fabricio, Taynara Incerti, Rodrigo Reis Leite, Guilherme Ferreira Gomes, José Henrique Ferreira Gomes, Anderson Paulo Paiva, and Pedro Paulo Balestrassi. 2018. A multivariate GR\&R approach to variability evaluation of measuring instruments in resistance spot welding process. Journal of Manufacturing Processes 36: 465-79. [CrossRef]

Aslam, Farhan, Wang Aimin, Mingze Li, and Khaliq Ur Rehman. 2020. Innovation in the Era of IoT and Industry 5.0: Absolute Innovation Management (AIM) Framework. Information 11: 124. [CrossRef]

Barnett, Tim, Allison W. Pearson, Rodney Pearson, and Franz W. Kellermanns. 2015. Five-factor model personality traits as predictors of perceived and actual usage of technology. European Journal of Information Systems 24: 374-90. [CrossRef]

Bro, Rasmus, and Henk A. L. Kier. 2003. A new efficient method for determining the number of components in PARAFAC models. Journal of Chemometrics 17: 274-86. [CrossRef]

Bucko, Jozef, Lukas Kakalejcík, and Martina Ferencova. 2018. Online shopping: Factors that affect consumer purchasing behavior. Cogent Business \& Management 5: 1535751. [CrossRef]

Civelek, Mehmet, Krzysztof Gajdka, Jaroslav Svetlik, and Vladimir Vavrecka. 2020. Differences in the usage of online marketing and social media tools: Evidence from Czech, Slovakian and Hungarian SMEs. Equilibrium. Quarterly Journal of Economics and Economic Policy 15: 537-63. [CrossRef]

Dempsey, Nicola, Glen Bramley, Sinead Power, and Caroline Brown. 2011. The social dimension of sustainable development: Defining urban social sustainability. Sustainable Development 19: 289-300. [CrossRef]

Drugău-Constantin, Andrea. 2019. Is Consumer Cognition Reducible to Neurophysiological Functioning? Economics, Management, and Financial Markets 14: 9-14. [CrossRef]

Duncan, Jennifer L., Bharath M. Josiam, Young Hoon Kim, and Alexandria C. Kalldin. 2015. Using factor-cluster analysis to segment patrons of casual dining establishments in the United States. British Food Journal 117: 1377-98. [CrossRef]

Fu, Hanliang, Gunasekaran Manogaran, Kuang Wu, Ming Cao, Song Jiang, and Aimin Yang. 2020. Intelligent decision-making of online shopping behavior based on internet of things. International Journal of Information Management 50: 515-25. [CrossRef]

Gburova, Jaroslava, and Richard Fedorko. 2018. Online shops and online shopping from the point of view of the Slovak consumer. Paper presented at the 36th International Scientific Conference on Economic and Social Development-Building Resilient Society, Zagreb, Croacia, December 14-15; pp. 134-40.

Ghobakhloo, Morteza. 2020. Industry 4.0, digitization, and opportunities for sustainability. Journal of Cleaner Production 252: 119869. [CrossRef] 
Giao, Ha Nam Khanh. 2020. Customer Satisfaction at Tiki. vn E-Commerce Platform. Journal of Asian Finance, Economics, and Business 7: 173-83. [CrossRef]

Graessley, Scott, Jakub Horak, Maria Kovacova, Katarina Valaskova, and Milos Poliak. 2019. Consumer Attitudes and Behaviors in the Technology-Driven Sharing Economy: Motivations for Participating in Collaborative Consumption. Journal of Self-Governance and Management Economics 7: 25-30. [CrossRef]

Hennessy, Brittany. 2018. Influencer: Building Your Personal Brand in the Age of Social Media. New York: Kensington Publishing Corp., pp. $18-19,131-32$.

Heureka. 2019. Slovaks Set a New Record on E-Shops-They Spent 1.36 Billion Euros. Available online: https:/ / onas.heureka.cz/ slovaci-v-roku-2019-na-e-shopoch-vytvorili-novy-rekord-minuli-136-miliardy-eur (accessed on 15 December 2020).

Hollowell, Jane Catherine, Zuzana Rowland, Tomas Kliestik, Jana Kliestikova, and Victor V. Dengov. 2019. Customer Loyalty in the Sharing Economy Platforms: How Digital Personal Reputation and Feedback Systems Facilitate Interaction and Trust between Strangers. Journal of Self-Governance and Management Economics 7: 13-18. [CrossRef]

Hoyer, Wayne D., and Deborah J. Macinnis. 2009. Consumer Behavior, 5th ed. Mason: South-Western, 493p.

$\mathrm{Hu}$, Litze, and Peter M. Bentler. 2009. Cutoff criteria for fit indexes in covariance structure analysis: Conventional criteria versus new alternatives. Structural Equation Modeling 6: 1-55. [CrossRef]

Jabbour, Charbel J. Chiappetta, Ana Beatriz Lopes de Sousa Jabbour, Joseph Sarkis, and Moacir Godinho Filho. 2019. Unlocking the circular economy through new business models based on large-scale data: An integrative framework and research agenda. Technological Forecasting and Social Change 144: 546-52. [CrossRef]

Jankalova, Miriam, and Jana Kurotova. 2020. Sustainability Assessment Using Economic Value Added. Sustainability 12: 318. [CrossRef]

Jeon, Hyeon Gyu, Cheong Kim, Jungwoo Lee, and Kun Chang Lee. 2021. Understanding E-Commerce Consumers' Repeat Purchase Intention: The Role of Trust Transfer and the Moderating Effect of Neuroticism. Frontiers in Psychology 12: 690039. [CrossRef] [PubMed]

Jungle Scout. 2021. Consumer Trends Report Q4 2021. Available online: https://www.junglescout.com/wp-content/uploads/2021/1 1/Jungle-Scout-Consumer-Trends-Report-Q4-2021.pdf (accessed on 15 October 2021).

Kakalejcík, Lukas, and Jozef Bucko. 2018. Mobile Shopers: Ako Nakupujú Majitelia Smartfónov. [Mobile Shopers: How Smartphone Owners Shop]. Košice: Technical University, 89p.

Lim, Yi Jin, Abdullah Osman, Shahrul Nizam Salahuddin, Abdul Rahim Romle, and Safizal Abdullah. 2016. Factors influencing online shopping behavior: The mediating role of purchase intention. Paper presented at the 7th International Economics \& Business Management Conference (IEBMC 2015), Kuantan, Malaysia, October 5-6.

Meilhan, Deborah. 2019. Customer Value Co-Creation Behavior in the Online Platform Economy. Journal of Self-Governance and Management Economics 7: 19-24. [CrossRef]

Mirică (Dumitrescu), Catalina-Oana. 2019. The Behavioral Economics of Decision Making: Explaining Consumer Choice in Terms of Neural Events. Economics, Management, and Financial Markets 14: 16-20. [CrossRef]

Misik, Tomas, Jana Stofkova, and Natalia Stalmasekova. 2018. Survey of increasing digital skills of university students. Paper presented at the 11th Annual International Conference of Education, Research and Innovation, Valencia, Spain, November 12-14; pp. 3949-56.

Nielsen. 2018. Online Shoping: Fashion First. Available online: https://www.nielsen.com/sk/sk/insights/news/2018/onlineshopping-fashion-first.html (accessed on 19 November 2019).

OECD. 2021. OECD Economic Outlook. Paris: OECD Publishing, vol. 2021, Issue 2. [CrossRef]

Pollák, František, Michal Konečný, and Deniss Ščeulovs. 2021. Innovations in the Management of E-Commerce: Analysis of Customer Interactions during the COVID-19 Pandemic. Sustainability 13: 7986. [CrossRef]

Polman, Evan, and Kaiyang Wu. 2020. Decision making for others involving risk: A review and meta-analysis. Journal of Economic Psychology 77: 102184. [CrossRef]

Popescu, Gheorghe H., and Florin Cristian Ciurlău. 2019. Making Decisions in Collaborative Consumption: Digital Trust and Reputation Systems in the Sharing Economy. Journal of Self-Governance and Management Economics 7: 7-12. [CrossRef]

Shoptet. 2021. Slovak E-Commerce Is Not Slowing Down. Available online: https:/ /blog.shoptet.sk/slovensky-e-commerce-q3-2021/ (accessed on 15 October 2021).

Soltes, Viktor, and Stanislav Stofko. 2017. Selected aspects of quality of life during the process of globalization. Paper presented at the 17th International Scientific Conference Globalization and Its Socio-Economic Consequences, Zilina, Slovakia, October 4-5; pp. 2439-46.

Stefko, Robert, Radovan Bacik, Richard Fedorko, Maria Olearova, and Martin Rigelsky. 2019. Analysis of consumer preferences related to the use of digital devices in the e-commerce dimension. Entrepreneurship and Sustainability 7: 25-33. [CrossRef]

Taher Al-Lami, Ghadi. 2021. E-Commerce: Advantages and Limitations. International Journal of Academic Research in Accounting Finance and Management Sciences 11: 153-65.

Tutz, Gerhard. 2021. Hierarchical models for the analysis of Likert scales in regression and item response analysis. International Statistical Review 89: 18-35. [CrossRef]

Valaskova, Katarina, Pavol Durana, and Peter Adamko. 2021. Changes in Consumers' Purchase Patterns as a Consequence of the COVID-19 Pandemic. Mathematics 9: 1788. [CrossRef] 
Vijayasarathy, Leo R. 2004. Predicting consumer intentions to use on-line shopping: The case for an augmented technology acceptance model. Information \& Management 41: 747-62. [CrossRef]

World Trade Organization (WTO). 1998. Work Programme on Electronic Commerce. Available online: https:/ / docs.wto.org/dol2fe/ Pages/SS/directdoc.aspx?filename=q:/WT/L/274.pdf\&Open=True (accessed on 15 December 2021).

Zafar, Muhammad Wasif, Shah Saud, and Fujun Hou. 2019. The impact of globalization and financial development on environmental quality: Evidence from selected countries in the Organization for Economic Co-operation and Development (OECD). Environmental Science and Pollution Research 26: 13246-62. [CrossRef] [PubMed] 